\title{
Jan Axelson in memoriam
}

\author{
HENRIK WILLIAMS
}

Jan Axelson, Isländska sällskapets skattmästare, avled 17 november i fjol, 59 år gammal. Som en av dem som har känt Jan längst känner jag mig kallad att skriva några ord om honom. Mina första minnen stammar från cirka 1980 då en ung man som visade sig vara Jan började hälsa på mig när vi stötte ihop, utan att jag kände honom. Förklaringen var en gemensam vän, Ola Larsmo, som läste svenska och teologi tillsammans med Jan och som hade pekat ut mig som någon som var intresserad av fornnordiska, ett av Jans intressen. Genom Ola har jag fått veta en del om Jans studietid. Han var en lysande student som olika lärare verkligen uppmärksammade som en studiebegåvning av första rang. Redan under sin gymnasiegång i Köping uppenbarades hans begåvning, vilket han aldrig själv lät påskina men som framgick genom olika historier han berättade under åren. Växte upp gjorde han i Kolsva som enda barnet till två äldre föräldrar och en exemplarisk son måste han ha varit under hela deras livstid. Med tiden kom han att sköta om mer och mer av det praktiska åt dem och mot slutet tog han tjänstledigt i perioder för att kunna hjälpa till på plats. När hans mamma dog följde pappan efter inom kort och de begravdes i samma grav vid Malma gamla kyrka där nu också Jans aska vilar.

Jans och mina vägar möttes på riktigt när han började på C-seminariet för att skriva uppsats. Ämnet han valde med Lena Peterson som handledare var ortnamnet Barkestorp i Småland. Det tog honom flera år att slutföra uppsatsen, men den är också ett riktigt lärdomsprov. Fördröjningen hade sin förklaring delvis i att Jan ägnade sig åt annat men i ännu högre grad tror jag i karaktärsdrag som alltmer kom att prägla hans liv. Jan var extremt plikttrogen, till den grad att det påverkade socialt umgänge och

Williams, Henrik. 2020. Jan Axelson in memoriam.

Scripta Islandica 71: 5-8.

(C) Henrik Williams (CC BY)

DOI: $10.33063 /$ diva-429318 


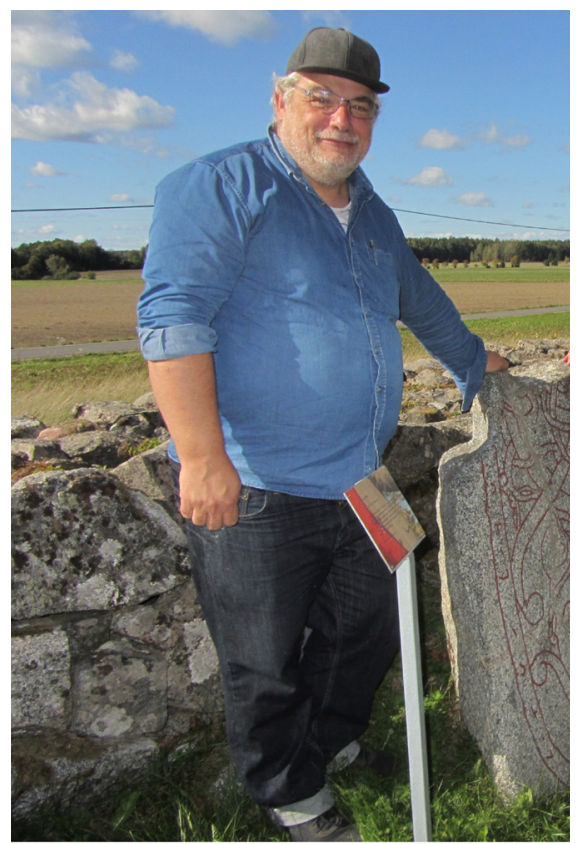

Jan Axelson med runsten U 1170 vid Vittinge kyrka. Foto: Gunnel Ollas, 2018.

yrkeskarriär. Under studietiden kom kurskraven först och sällskapet med vänner och bekanta blev lidande trots att Jan var mycket social och gärna deltog i olika arrangemang. Egna initiativ tog han däremot inte ofta nog och så småningom ledde det till en viss ensamhet, även om hans umgänge var långt större än någon av oss visste eftersom han för andra bekanta aldrig berättade vem han hade träffat.

Jan arbetade under flera år på Runverket vid Riksantikvarieämbetet och hade nog hoppats få fortsatt anställning där eller på Svenskt diplomatarium vid Riksarkivet som han också arbetade vid under en period. Hans kompromisslösa noggrannhet vid utförandet av alla arbetsuppgifter ledde dock till en alltför låg produktivitet. Tillsammans med Svante Lagman och mig bildade Jan en runologisk doktorandtrio, även om han antogs senare än vi andra två. Hans avhandling skulle handla om fornärvda diftonger i runsvenskan. Ämnet är ytterst komplext och Jan kom aldrig längre än till en omfattande materialinsamling som dessutom gick förlorad genom datorproblem. En kortare analystext som jag fick läsa visade dock att han var på rätt spår. De tidigare nämnda problemen med att få saker ur 
händerna gjorde sig allt mer gällande, och den värdefulla inventering av mellansvenska runristare han publicerade 1993 tog mycket längre tid än beräknat.

Sin fasta yrkesbas hade Jan som studievägledare vid Institutionen för nordiska språk i Uppsala. Han slutförde sin ämneslärarutbildning men arbetade såvitt jag vet aldrig på högstadiet eller gymnasiet. Vid Institutionen var han en tid universitetsadjunkt tills hans tjänst ändrade beskrivning, och som sådan hade han viss undervisning men det var som administratör hans egentliga insats bestod. Efter att heltidsadjunkturen förvandlats till en halvtidstjänst fortsatte Jan arbeta lika mycket om inte mer, men han hann uppleva glädje att sista året få gå upp på heltid igen. Efter hans död sades det inte bara på skämt att hans anställning fick ersättas av tre heltidstjänster. Jan satt också på jobbet minst sex dagar i veckan och ofta inpå sena kvällen. Jag brukade övertala honom att följa mig en bit på vägen hem eftersom vi bodde åt samma håll. Förutom dessa promenader och ganska många samtal på tjänsterummen umgicks vi inte mycket privat, förutom på julafton då Jan under många år var vår gäst vid jullunchen, under Kalle Anka på teve efteråt och julbönen i Domkyrkan.

I kyrkan gick Jan varje vecka. Han växte upp i Missionskyrkan men lämnade den och gick de sista åren mest i Vindhemskyrkan (Svenska kyrkan) där han också jordfästes den 7 februari i år. Hans kyrkliga bakgrund märktes inte minst genom en imponerade bibelsprängdhet. Jans kunskaper omfattade mycket mer än så och han verkade ibland komma ihåg allt han lärt sig i skolan eller på universitetet. Så tog han ibland kurser flera gånger och gick inte upp i förhör förrän han hade fäst varenda detalj i minnet. En gång fick han väl godkänt på fördjupningskursen i fornisländska, men eftersom han inte varit formellt berättigad att gå kursen tenterade han om för annan lärare när han skaffat sig sin behörighet.

Obehöriga studenter var han annars väl bekant med, inte minst eftersom jag envisades att låta sådana följa mina kurser. Efter att ha gett mig en sträng tillrättavisning för mina synder löste han alltid de administrativa problem jag hade åsamkat på bästa sätt för studenten ifråga, dock utan att någonsin tumma på reglerna. De tusentals studenter, inte minst de utländska, som under årtiondena har haft förmånen att åtnjuta Jans hjälpsamhet vet vad jag talar om. Så fylldes också Ihresalen av studenter som jämte kollegorna deltog i minnesstunden efter hans överraskande dödsfall. Som prästen sade vid hans också mycket välbesökta jordfästning var det inte en tillfällighet att Jan dog av för stort hjärta.

Jan var en tjänsteman av gamla skolan och hade bland sina många jobb 
också vikarierat på fakultetskansliet. Han hade bestämmelser på sina fem fingrar och var en tillgång både vad gällde det som för tillfället gällde och det som en gång rådde. Dessutom var han vår främste institutionshistoriker som vårdade sig om minnen och vid ett tillfälle räddade den dyrbara samlingen av fornisländsk litteratur från att införlivas med det gemensamma biblioteket $\mathrm{i}$ kvarteret. Många gånger har jag skänkt hans framsynthet en tacksamhetens tanke.

Jan satte aldrig sig själv i första rummet och utmärktes av en för långt driven ödmjukhet som kan ställa till problem den med. Många hedersbevis skämdes han inte bort med, men jag vet att han var stolt över att bli vald till Isländska sällskapets skattmästare, en syssla han skötte med omsorg. Jag hade själv detta uppdrag 1986-92 och ansvarade de första åren också för medlemsregister samt utskick av kallelser och årsskrift till de över 200 medlemmarna. Jan ställde flera gånger upp och hjälpte till med att stoppa Scripta Islandica i kuverten, liksom man kunde räkna med att han hjälpte till med röjningen efter postseminarier och sexor.

Trogen sin frikyrkliga bakgrund var Jan livslång nykterist. Såvitt jag vet drack han alkohol bara en gång. Jag hade av runologen, numera vintillverkaren Claiborne Thompson i Kalifornien fått en flaska av deras finaste vin, The Runestone Wine. Jag sparade flaskan ett par år men öppnade den tillsammans med några andra runforskare för att fira en befordran. Till min stora förvåning gjorde Jan ett undantag och ville testa runvinet, han också. Till stor besvikelse för oss andra hade vinet hunnit bli dåligt och ingen ville dricka det. Utom Jan som tömde sin lilla skvätt; hur skulle han kunna ha vetat hur vin ska smaka?

Kanske är det ett passande slut på minnesordet över en oerhört principfast människa som aldrig gjorde stort väsen av sig och kunde göra undantag när det kom till kritan. Jag saknar honom nästan varje dag, hans vänlighet och hjälpsamhet, hans integritet och humoristiska allvar, men mest av allt hans rena godhet. Människor som Jan Axelson är alltför sällsynta.

Henrik Williams

Uppsala universitet

Institutionen för nordiska språk

ORCID iD 0000-0003-1738-7072 